\title{
The effect of feeding diets differing in protein and energy concentration on fattening performance of three pig crossbreeds
}

\author{
J.L. Sokól' ${ }^{1}$, J. Kulisiewicz ${ }^{2}$, J. Skomial ${ }^{1}$ and Ewa Sawosz ${ }^{1}$ \\ 'Department of Animal Nutrition and Feed Management \\ 'Department of Animal Breeding \\ Warsaw Agricultural University \\ Rakowiecka 26/30, 02-528 Warsaw, Poland
}

(Received 20 August 1996; accepted 15 May 1997)

\begin{abstract}
In an experiment performed on three types of pig crossbreeds derived from crossing Polish Large White (PLW) x Polish Landrace (PL) sows with Duroc, Pietrain or Duroc x Pietrain boars, the effect of increased protein level (17.3 vs $15.4 \%$ ) in feed mixture with low energy level $(11.8 \mathrm{MJ} / \mathrm{kg})$, and increased both protein and energy levels (to $17.3 \%$ and $12.9 \mathrm{MJ} / \mathrm{kg}$, respectivcly) on fattening performance, carcass and meat quality, nutrients digestibility and nitrogen balance werc studicd.

The best fattening performance, energy and protein utilisation were obtained from crosses of Duroc or Pietrain boars. The progeny of Pietrain boars had also the highest meat yield $(65 \%)$ and the lowest carcass fat content.

Increased crude protein content in the mixture did not affect significantly the live weight gains ( 693 vs. $711 \mathrm{~g}$ ) or metabolisable energy conversion ( 36.2 vs. $35.4 \mathrm{MJ} / \mathrm{kg}$ gain), but decreased crudc and digestible protein utilisation per $\mathrm{kg}$ of live weight gain. Increasing both protein and energy concentration in the mixture significantly $(P<0.05)$ increased live weight gains $(768$ vs. $693 \mathrm{~g})$.
\end{abstract}

KEY WORDS: crossbreeds, Pietrain, Duroc, protein, energy, fattening, slaughter value, digestibility, nitrogen balance, pig

\section{INTRODUCTION}

The potential of the domestic pig population for protein deposition has not been sufficiently recognized, the more so as not only pure breeds but also numerous crosses are used for fattening. According to Fandrejewski (1995) it is 
therefore difficult to define pigs requirement for energy and nutrients since they should be based on expected growth rate and protein and fat deposition.

According to Close (1993), genetically improved pigs that gain even $1200 \mathrm{~g}$, are capable of depositing about $200 \mathrm{~g}$ of protein daily and their energy requirement for maintenance is $10 \%$ higher than given in the ARC Standards (1981). In that author's opinion this is related to the greater rate of protein deposition in the body and its faster metabolism. The protein of rate deposition depends also on the dietary concentration of this component (Fabijańska, 1992).

Many studies published to date have examined the relationship between the genotype of pigs and feeding level (Fandrejewski and Kazanecka, 1987; Kovach et al., 1987; Evans et al.,1988; Kotarbińska et al., 1989; Cameron, 1990; Kanis, 1990; Kempster et al., 1990). Fewer studies have focused on the interdependence of genotype and protein and energy requirements, and on the optimal proportions of these feed constituents. The results of the few studies are inconsistent (Peterson, 1978a,b; Christian et al., 1980; Panajotov et al., 1984; Savidge et al., 1984; Benkov et al., 1986). Several authors claim that the determining nutritional requirements of crossbred pigs requires knowledge about the interrelationship between dietary energy, protein and amino acids contents, and their efficiency of utilisation (Close, 1993).

The objective of the study was to determine the effect of an increase of protein content in feed mixture with lower energy level, and an increase of both protein and energy concentration on the fattening performance and carcass value, digestibility of nutrients, and nitrogen balance in three different pig crossbreeds.

\section{MATERIAL AND METHODS}

The experiment was carried out on three groups of 18 fattening pigs each. In group I (control) the animals were fed on a feed mixture containing $15.4 \%$ crude protein and $11.8 \mathrm{MJ} \mathrm{ME} / \mathrm{kg}$. In the feed given to pigs in group II protein level was increased about $10 \%(17.3 \%)$ while in the mixture fed to pigs in group $11 \mathrm{l}$ both protein and energy concentrations were increased to $17.3 \%$ and $12.9 \mathrm{MJ} \mathrm{ME} / \mathrm{kg}$, respectively.

The protein content in mixtures fed to experimental groups (II and III) was increased by substituting soyabean oilmeal for part of barley in control feed while increasing of energy content in feed for group III was obtained by supplementing with a fat concentrate. The composition and nutritional value of diets are presented in Table 1.

Each feeding group comprised 6 fatteners ( 3 gilts and 3 barrows) of the following genotypes: 
Composition and nutritional value of dicts

\begin{tabular}{|c|c|c|c|}
\hline \multirow[b]{2}{*}{ Indices } & \multicolumn{3}{|c|}{ Group } \\
\hline & I & II & III \\
\hline \multicolumn{4}{|l|}{ Composition of diets, $\%$} \\
\hline protein concentrate ${ }^{l}$ & 17.0 & 17.0 & 17.0 \\
\hline ground barlcy & 63.0 & 67.0 & 60.5 \\
\hline wheat bran & 10.0 & 10.0 & - \\
\hline soyabean oilmeal & - & 6.0 & 7.5 \\
\hline fat concentrate ${ }^{2}$ & - & - & 15.0 \\
\hline \multicolumn{4}{|l|}{ Chemical composition, $\mathrm{g} / \mathrm{kg}$} \\
\hline crude protein & 15.4 & 17.3 & 17.3 \\
\hline digestible protein & 11.0 & 13.2 & 13.2 \\
\hline ether extract & 2.5 & 2.4 & 7.8 \\
\hline crude fibre & 4.9 & 4.5 & 4.2 \\
\hline $\mathrm{N}$-free extractives & 59.5 & 57.7 & 53.3 \\
\hline lysine & 8.2 & 9.3 & 9.6 \\
\hline methionine + cystine $^{3}$ & 5.7 & 6.1 & 6.1 \\
\hline calcium $^{3}$ & 8.6 & 8.7 & 8.7 \\
\hline total phosphorus & 8.0 & 8.1 & 8.0 \\
\hline Metabolizable energy, $\mathrm{MJ} / \mathrm{kg}$ & 11.8 & 11.8 & 12.9 \\
\hline
\end{tabular}

' composition, \%: soyabean oilmeal 40.5, rapeseed oilmeal "00" 30.0, meat-and-bone meal 20.0, mikromix PT2-3.0 phosphate 3.0, $\mathrm{NaCl} 1.8$, limestone 0.5 , L-lysine 1.0, DL-methionine 0.2

${ }^{2}$ wheat bran $66 \%$; industrial fat $34 \%$

${ }^{3}$ calculated according to Nutrient Requirements of Pigs (1993)

- 9 (PLW x PL) x $\delta$ Duroc

$-\phi$ (PLW x PL) x $\overbrace{}^{\top}$ Pietrain

- $९$ (PLW x PL) x $\curvearrowright$ (Duroc x Pietrain).

The crossbreeds were from spring litters, from 12 sows (PLW x PL) and 6 boars (Duroc 2, Pietrain 2, Duroc x Pietrain 2).

During the 112-days fattening period, from about $23 \mathrm{~kg}$ initial live weight, the fatteners were fed individually on respective diets in amounts increased every 2-3 weeks from 1.2 to $3.0 \mathrm{~kg}$, in two daily portions $(7.00$ and $14.00 \mathrm{~h})$, mixed with water $(1: 1)$.

In the middle of the fattening period, when the pigs had reached a body weight of about $65 \mathrm{~kg}$, nutrients digestibility and nitrogen balance were determined on 6 barrows from each feeding group, two of each genotype. During the 6-day collection, faeces were preserved with chloroform, urine with $10 \% \mathrm{HCl}$. Pigs used to determine nitrogen balance (18 barrows) were slaughtered after reaching body weight of about $110 \pm 0.9 \mathrm{~kg}$, and their slaughter performance and carcass value were determined. The right side of carcass was dissected according to the Pig Progeny Station method. 
The content of nutrients in feeds and faeces, as well as the nitrogen content in urine samples were determined with conventional methods using Tecator equipment. The metabolisable energy content in the mixtures was calculated according to adjusted Rostock equations (DLG, 1991) in which the results of chemical analyses and digestibility coefficients obtained experimentally were used.

The results were subjected to statistical analysis by the least squares method according to Harvey (L.S.M.L.M.W., 76 software).

\section{RESULTS}

Highly significant differences $(\mathrm{P}<0.01)$ were found among the groups in the digestibility coefficients of protein and fat (Table 2). The highest protein digestibility was in the pigs of groups II and III receiving diet with higher level of protein, fat digestibility was the highest in group III. No differences were found in the digestibility of nutrients among the pigs from various genetic groups. There were, however, differences $(P<0.05)$ in the nitrogen balance: nitrogen retention and utilisation was higher in crossbreeds of Duroc or Pietrain boars, than in the progeny of Duroc $x$ Pietrain boars.

The pigs in group III had the highest daily weight gains ( $768 \mathrm{~g}$ ) (Table 3 ). The final weight of the animals differed by about $8 \mathrm{~kg}$ among groups, ranging from almost 101 in group I to over $109 \mathrm{~kg}$ in group III. Increasing the protein level in

TABLE 2

Coefficients of apparent digestibility and $\mathrm{N}$ balance

\begin{tabular}{|c|c|c|c|c|c|c|c|}
\hline \multirow{3}{*}{ Indices } & \multicolumn{6}{|c|}{ Group } & \multirow{3}{*}{$\mathrm{SE}$} \\
\hline & \multicolumn{3}{|c|}{ breed } & \multicolumn{3}{|c|}{ diet } & \\
\hline & Duroc & Pietrain & $\begin{array}{c}\text { Duroc } \mathrm{x} \\
\text { Pietrain }\end{array}$ & I & II & III & \\
\hline \multicolumn{8}{|c|}{ Digestibility coefficients, \% } \\
\hline crude protein & 75.3 & 73.2 & 75.1 & $71.2^{\mathrm{B}}$ & $76.3^{\mathrm{A}}$ & $76.1^{\mathrm{A}}$ & 0.9 \\
\hline ether extract & 43.5 & 43.0 & 41.1 & $39.2^{\mathrm{Ba}}$ & $14.1^{\mathrm{Bh}}$ & $74.2^{A}$ & 9.4 \\
\hline organic matter & 80.1 & 80.8 & 80.8 & 81.3 & 80.8 & 79.6 & 1.7 \\
\hline N-retained, g/day & $21.1^{\mathrm{a}}$ & $20.6^{\mathrm{a}}$ & $17.8^{\mathrm{b}}$ & 18.7 & 20.7 & 20.1 & 1.6 \\
\hline$\%$ of intake & $35.9^{\mathrm{a}}$ & $35.6^{\mathrm{a}}$ & $30.3^{\mathrm{b}}$ & 34.9 & 34.0 & 33.0 & 2.6 \\
\hline$\%$ of digested & $47.8^{\mathrm{a}}$ & $48.4^{a}$ & $40.4^{b}$ & 48.5 & 44.7 & 43.3 & 3.4 \\
\hline
\end{tabular}


TABLE 3

Animal performance

\begin{tabular}{|c|c|c|c|c|c|c|c|}
\hline \multirow{3}{*}{ Indices } & \multicolumn{6}{|c|}{ Group } & \multirow{3}{*}{ SE } \\
\hline & \multicolumn{3}{|c|}{ breed } & \multicolumn{3}{|c|}{ diet } & \\
\hline & Duroc & Pietrain & $\begin{array}{c}\text { Duroc x } \\
\text { Pictrain }\end{array}$ & I & II & III & \\
\hline \multicolumn{8}{|l|}{ Body weight, kg } \\
\hline initial & 23.4 & 24.1 & 22.6 & 23.3 & 23.4 & 23.4 & 0.9 \\
\hline final & $106.2^{\mathrm{a}}$ & $104.8^{\mathrm{a}}$ & $102.5^{\mathrm{b}}$ & $100.9^{y}$ & $103.1^{\mathrm{B}}$ & $109.4^{\mathrm{A}}$ & 1.3 \\
\hline Daily live weight gain, $g$ & $739^{\mathrm{a}}$ & $734^{a}$ & $700^{\mathrm{b}}$ & $693^{\mathrm{B}}$ & $711^{B}$ & $768^{\wedge}$ & 13 \\
\hline \multicolumn{8}{|l|}{ Per $1 \mathrm{~kg}$ gain } \\
\hline ME, MJ & $35.1^{\mathrm{a}}$ & $35.2^{\mathrm{a}}$ & $36.4^{\mathrm{b}}$ & 36.2 & 35.4 & 35.1 & 0.7 \\
\hline crude protein, g & $480^{a}$ & $482^{\mathrm{a}}$ & $498^{\mathrm{b}}$ & $470^{\mathrm{A}}$ & $518^{\mathrm{R}}$ & $471^{\mathrm{A}}$ & 9 \\
\hline digestible protein, $\mathrm{g}$ & $358^{a}$ & $360^{\mathrm{a}}$ & $371^{\mathrm{b}}$ & $335^{A}$ & $395^{\mathrm{C}}$ & $359^{\mathrm{B}}$ & 7 \\
\hline
\end{tabular}

$\mathrm{a}, \mathrm{b}-\mathrm{P}<0.05$

A. B, C $-\mathrm{P}<0.01$

diet II without raising the energy level did not significantly increase weight gains, but did lead to increased protein use per $\mathrm{kg}$ of weight gain.

Analysis of the fattening performance of the genetic types of pigs showed that crossbreeds of Duroc or Pietrain boars, gained considerably better and used less energy and protein per kilogram weight gain than the crossbreeds of Duroc $x$ Pietrain boars $(P<0.01)$. No interaction was found between the feeding and genetic groups of the pigs.

TABLE 4

Slaughter performance and carcass value

\begin{tabular}{|c|c|c|c|c|c|c|c|}
\hline \multirow{3}{*}{ Indices } & \multicolumn{6}{|c|}{ Group } & \multirow{3}{*}{$\mathrm{SE}$} \\
\hline & \multicolumn{3}{|c|}{ breed } & \multicolumn{3}{|c|}{ diet } & \\
\hline & Duroc & Pictrain & $\begin{array}{r}\text { Duroc } x \\
\text { Pietrain }\end{array}$ & $\mathrm{I}$ & II & III & \\
\hline Carcass length, cm & $80.5^{\mathrm{A}}$ & $77.2^{\mathrm{B}}$ & $79.0^{\wedge}$ & 78.3 & 79.2 & 79.2 & 0.7 \\
\hline Cold dressing percentage, $\%$ & $76.2^{\mathrm{B}}$ & $78.6^{\mathrm{A}}$ & $76.6^{\mathrm{B}}$ & $76.8^{b}$ & $76.4^{\mathrm{b}}$ & $78.1^{\mathrm{a}}$ & 0.7 \\
\hline \multicolumn{8}{|l|}{$\begin{array}{l}\text { Backfat thickness } \\
\text { (mcan from }\end{array}$} \\
\hline 5 measurements), $\mathrm{mm}$ & $28.8^{\mathrm{B}}$ & $24.6^{\mathrm{A}}$ & $30.2^{\mathrm{B}}$ & 27.8 & 27.9 & 27.9 & 2.0 \\
\hline Loin eye area, $\mathrm{cm}^{2}$ & 45.2 & 52.3 & 51.8 & 52.8 & 47.0 & 49.5 & 5.0 \\
\hline Meat in ham, kg & $6.07^{\mathrm{B}}$ & $7.22^{\wedge}$ & $6.25^{\mathrm{B}}$ & 6.69 & 6.42 & 6.42 & 0.3 \\
\hline $\mathrm{pH}_{45}$ & $6.22^{\mathrm{a}}$ & $5.85^{b}$ & $6.26^{\mathrm{a}}$ & 6.12 & 6.00 & 6.20 & 0.2 \\
\hline
\end{tabular}

$\mathrm{a}, \mathrm{b}-\mathrm{P}<0.05$

${ }^{\wedge}, \mathrm{B}-\mathrm{P}<0.01$ 
Large differences in meat quality were found among the genetic types of pigs $(\mathrm{P}<0.01)$. The progeny of Pietrain boars had the shortest half carcass, and the highest dressing percentage, the thinnest backfat, the highest lean percentage in the ham and the highest lean percentage in the basic cuts. The crossbreeds of Pietrain boars had the lowest $\mathrm{pH}_{45}$ of meat (Table 4). Among the slaughter performance parameters, significant differences $(P<0.05)$ between feeding groups were found only in the dressing percentage which was the highest in group III.

\section{DISCUSSION}

Increasing the protein content in feed mixtures from 15.4 to $17.3 \%$ resulted in higher apparent protein digestibility (from about 71 to $76 \%$ ). Similarly, increasing the fat content in the ration increased its digestibility; it is well known relationship between the amount of this nutrient in the diet and its digestibility. The higher protein digestibility did not, however, correlate with the nitrogen balance, which depended on the genotype of the animal, but not on the diet. A good correlation was found between nitrogen balance and productivity. The progeny of Duroc and Pietrain boars, which had higher nitrogen retention and utilisation than the progeny of Duroc $\mathrm{x}$ Pietrain boars, had also higher weight gains and utilized energy and protein more efficiently.

A positive response of crossbreeds of Pietrain boars to the increased protein content in the diet was expected since this breed was characterized by a high protein deposition capability accompanied by low fat deposition (Fuller et al., 1975; Cöp and Buiting, 1977; Peterson, 1978a; Gatel and Grosjean, 1992). However, despite the better performance in terms of most of the traits concerning carcass value, no interactions were found. No diet $x$ genotype interactions were found for fattening performance. This may have been due to the use of a standardized feeding scale, i.e. one in which feed intake was limited. According to some authors (Kovach et al., 1987; Kanis, 1990) the differentiated feed intake ability of animals of different genotypes is the main factor responsible for the variability of fattening performance. This conclusion is supported by the results of Quiniou et al. (1995) who showed that pigs fed according to standards not only deposited less protein, but also less fat than animals fed to appetite. However, Kulisiewicz et al. (1995) found no differences in fattening performance except the proportion of lean in the carcass, despite differentiated feed intake.

Increasing the content of meat in the carcass as the result of increasing the dietary protein or protein and energy levels was found in animals having $50 \%$ Pietrain genes. Fuller et al. (1995) point to a possible interrelationship between energy metabolism and the degree of fat deposition, suggesting that selection for 
lean carcasses could have led to retaining animals having higher energy losses. At the same time, animals that utilize dietary protein efficiently may show poorer response to increasing the level of this component in the diet. Fuller et al. (1995) suggest that crossbreeds of genetically different populations may differ in muscle gain. This may explain the worse fattening performance of four-breed crossbreeds as compared with three breed crosses, found in this study.

Fattening performance was improved only when the feed had increased both protein and energy contents while increasing only protein content did not result in any improvement. This was probably due to an energy deficit; the Nutrient Requirements of Pig (1993) recommend $13 \mathrm{~g}$ crude protein and $10 \mathrm{~g}$ digestible protein per $1 \mathrm{MJ}$ EM, while the feed with the increased protein content, used in this experiment, had 14.6 and $11.1 \mathrm{~g}$ crude and digestible protein per $1 \mathrm{MJ} \mathrm{EM}$, respectively. Rao and McCracken (1990), however, using various protein levels, found a significant positive effect of increasing protein content on protein deposition. A declining content of protein in the ration also led to increased fat deposition.

On the basis of the obtained results, it can be concluded that increasing protein level in the diet of highly productive fattening pigs requires a concomitant increase of the energy level in order to maintain the proper protein : energy ratio. It is difficult to unequivocally assess the influence of pigs genotype on feed utilization with different protein and energy contents. This indicates that more studies should be carried out on this problem.

\section{REFFRENCES}

ARC. 1981. The Nutrient Requirements of Pigs. Commonwealth Agricultural Bureaux, Slough

Benkov B.J., Panajotov P., Vasilev M., 1986. Interaction between genotype and amount of protein and amino acids in diets for fattening pigs (in Bulgarian). Živ. Nauki 23. (8), 22-30

Cameron N.D., 1990. Comparison of Duroc and British Landrace pigs and the estimation of genetic and phenotypic parameters of growth and carcass traits. Anim. Prod. 50, 141-153

Christian L., Strock K., Carlsson J., 1980. Effects of protein, breed cross, sex and slaughter weight on swine performance and carcass traits. J. Anim. Sci. 51, 51-58

Close W.H., 1993. Feeding new genotypes. Amino acid/energy rations. $54^{\text {th }}$ Easter School in Agricultural Science. Principles of Pig Science. University of Nottingham, pp. 24-25

Cöp W.A.G, Buiting G.A.J., 1977. Feed intake in six lines of pigs and its influence on growth and carcass traits. Anim. Prod. 25, 291-304

DLG-Futterwerttabellen - Schweine (1991). 6 Auflage, DLG-Verlag, Frankfurt am Main

Evans D., Kempester A., Steane D., 1988. Differential rates of genetic change and genotype $x$ enviroment interaction and a purcbred Large White population. Anim. Prod. 47, 457-466

Fabijańska M.,1992. Influence of different nitrogen fertilization on nutritional value of barley grain in fattening pig nutrition (in Polish). Thesis, Warsaw Agricultural University, pp. 46 
Fandrejewski H., Kazanecka M., 1987. Chemical body composition and slaughter value of Landrace and Duroc pigs fed restricted or ad libitum. Proceedings of $38^{\text {:h }}$ Meeting of EAAP, lisbona

Fandrejewski II., 1995. Importance of nutrition in pig production (in Polish). Prz. hod. 63 (3), 1-4

Fuller M.F., Franklin M.F., McWiliams R., Pennie K.,1995. The responses of growing pigs, of different sex and genotype, to dictary energy and protein. Anim. Sci. 60, 291-298

Gatcl F., Grosjean F., 1992. Performance of pigs from two genotypes in relation to the amino acid content of the diet. Livest. Prod. Sci. 30,129-140

Kanis E., 1990. Effect of feed intake capacity on genotype by feeding regimen interactions in growing pigs. Anim. Prod. 50, 343-351

Kempster A., London A., Evans D., Steane D., 1990. The effects of sire type and company source on litter productivity and pig growth performance. Anim. Prod. 50, 550, Abstr. 19

Kotarbińska M., Fandrejewski II., Kazanecka M., 1989. Daily protein deposition in weight gain of pigs Duroc, Polish Landrace -21 (pl-21) and crossbred $F_{1}$ (fathers Duroc $x$ mothers pl-2l (in Polish). Rocz. Nauk Zoot. 16, 17-24

Kovach G., Horn P., Vagyon L., Meszaros Z., 1987. Effect of feeding method (semi ad libitum and ad libitum) on feeding performance and carcass quality in different genotypes of hybrid pigs. Proceeding of $38^{\text {th }}$ Annual Meeting EAAP. Lisbona

Kulisiewicz J., Sokół J.L., Rekiel A., Inarski R., Lenartowicz. P., 1995. Growth rate and carcass value of three types of crossbred pigs fed ad libitum diets with different protein and energy contents. J. Anim. Feed Sci. 4, 11-19

Nutrient Requirements of Pigs. Tables of Nutritional Value of Feedstuffs (in Polish), 1993. The Kielanowski Institute of Animal Physiology and Nutrition (Editors), Jablonna

Panajotov P., Benkov B., Macher M., 1984. Fattening and meat production quality of hybrid pigs of different genotype given two amounts of protein (in Bulgarian). Živ. Nauki 21 (4), 36-45

Peterson U., 1978a. Einfluss der Proteinversorgung auf Mastleistung und Schlachtkörpermerkmale bei Schweinen der Rassen Pietrain und Deutsche Landrasse. Züchtungskunde 50, 26-38

Peterson U., 1978b. Vergleichende Untersuchungen über die Schlachtkörperzusammesctzung und die Ausbildung von Organen bei Schweinen der Rassen Pietrain und Deutsche Landrasse unter Berücksichtung der Proteinversorgung. Züchtungskunde 50, 208-217

Quiniou N., Noblet J., van Milgen J., Dourmad J.Y., 1995. Effect of energy intake on performance, nutrient and tissue gain and protein and encrgy utilization in growing boars. Anim. Sci. 61, 133-143

Rao D.S., McCracken K.J., 1990. Effect of protein intake on energy and nitrogen balance and chemical composition of gain in growing boars of high genetic potential. Anim. Prod. 51, 389-397

Savidge J.A., Cole D.J.A., Lewis D., 1984. A study of dietary encrgy density and genotype, interaction on voluntary food intake of the grower pig. Anim. Prod. 38, 535, Abstr. 61

\section{STRESZCZENIE}

Wpływ pasz zawierających zróżnicowaną zawartość bialka i energii na wyniki tuczu trzech typów mieszańców świń

W doświadczeniu na 54 tucznikach ( 3 grupy żywieniowe, w każdej po trzy typy mieszańców, pochodzących z krzyżowania loch wbp x z knurami rasy Duroc, Pietrain lub Duroc x Pietrain) określano wplyw zwiększenia zawartości bialka (z 15,4 do 17,3\%) w mieszance o zawartości 11,8 MJ 
energii metabolicznej oraz zwiçkszenia zawartości białka i cncrgii (do $17.3 \%$ i $12,9 \mathrm{MJ} / \mathrm{kg}$ paszy) na przebieg tuczu, strawność składników pokarmowych i bilans azotu oraz jakość tusz.

Tuczniki żywiono indywidualnie; paszę wilgotną podawano dwukrotnie w ciągu dnia, prze 112 dni od masy ciała ok. $23 \mathrm{~kg}$. Badanie bilansowe wykonano na 18 wieprzkach przy średniej masie ciała $65 \mathrm{~kg}$, a po osiągnięciu $110 \mathrm{~kg}( \pm 0,9)$ dokonano poubojowego rozbioru ich tusz.

Najlepsze wyniki tuczu (przyrosty, wykorzystanic energii), niczalcżnic od typu genetycznego świń, uzyskano przy skarmianiu mieszanki o równocześnie zwiększonej (o ok. 10\%) zawartości bialka i energii. Podniesienie w mieszance wyłącznie poziomu białka spowodowało wiz̨ks/e zuzycie tego składnika na $1 \mathrm{~kg}$ przyrostu.

Porównując poszczególne typy świń stwicrdzono, że mieszańcc typu Duroc [O (wbp x pbz) $\mathbf{x} \delta$ Duroc] oraz Pietrain $\left[Q\right.$ (wbp x pbz) $x{ }^{*}$ Pietrain] miały większe przyrosty, lepicj wykorzystywały paszę i odkładały więcej azotu niż mieszańce po knurze Duroc x Pietrain [q (wbp x pbz) x ổ (Duroc $x$ Pietrain)]. Najwyższą natomiast mięsnością charakteryzowaly się mieszańce typu Pietrain. 